Daniel L. Thornton is an assistant vice president and economist at the Federal Reserve Bank of St. Louis. Jonathan Ahlbrecht provided research assistance.

\section{Does the Fed's New Policy of Immediate Disclosure Affect the Market?}

\section{Daniel L. Thornton}

$\mathrm{U}$ ntil its February 1994 meeting, the Federal Open Market Committee (FOMC) followed the practice of announcing a "policy directive" approximately 45 days after the meeting in which it had been approved. ${ }^{1}$ This practice of delaying announcements had prompted some in Congress and the media to accuse the Fed of being unnecessarily secretive. ${ }^{2}$ While there is no long-term record of the Fed's views on immediate disclosure of policy decisions, the Fed had argued in a 1976 Freedom of Information Act filing that announcing policy decisions immediately would commit it to a course of action, thereby impairing its ability to conduct monetary policy flexibly. Moreover, the Committee argued, the immediate announcement of policy decisions would create an undesirable "announcement effect," thereby increasing the volatility of financial markets. Critics countered that the Fed's failure to convey its intentions to the market in a timely fashion increased financial market uncertainty and volatility. Some maintained that the Fed's disclosure practice effectively gave preference to large, sophisticated investors over average investors.

While it is uncertain when the Fed's position on immediate disclosure of FOMC policy decisions changed, the FOMC broke with tradition at its February
1994 meeting and announced a policy directive change immediately after voting on it. ${ }^{3}$ Although the Fed made no commitment to continue this practice, the next five policy changes were announced immediately and the FOMC formalized the practice of immediate disclosure at its February 1995 meeting. ${ }^{4}$

The purpose of this article is to investigate whether and how financial markets have responded to this change in the FOMC's disclosure policy. ${ }^{5}$ Specifically, I investigate (1) whether the policy of immediate disclosure has created an announcement effect, and (2) whether the policy of immediate disclosure has increased or reduced financial market uncertainty.

\section{Changes in the Fed Funds Target: Is There an Announcement Effect?}

Since at least the mid-1980s the Fed has conducted monetary policy by making relatively small adjustments to its target for the federal funds rate. ${ }^{6}$ The period covered by this study-January 4, 1988, through January 31,1996 - is one of federal funds rate targeting. A summary of changes in the Fed's target for the federal funds rate during this period is presented in Table 1. There were 48 changes in the Fed's funds rate target-38 prior to 1994 and 10 after $1994 .{ }^{7}$ Fourteen of these announcements were accompanied by announcements of changes in the discount rate- 9 prior to 1994 and 5 after. In addition, of the 38 changes prior to 1994, 9 were made at meetings of the FOMC. Since 1994, all but one change in the Fed's target for the funds rate have been made at FOMC meetings. ${ }^{8}$

The first step in this investigation is to see if there is any validity to the Fed's claim that immediate disclosure of its policy decisions would give rise to an "announcement effect" - a significant reaction to changes in the Fed's federal funds
${ }^{1}$ FOMC (1977). See Belongia and Kliesen $(1994$, p. 80) for details.

2 See Goodfriend (1986); O'Brien (1981, 1984); Belongia and Kliesen (1994); Whalen (1993); and Gonzalez (1994).

3 See Pakko (1995) for more information on FOMC discussions of disclosure policy.

${ }^{4}$ See Board of Governors of the Federal Reserve (1995).

5 This paper was motivated by work by Graciela Kaminsky on the change in the Fed's disclosure policy. The results for the announcement effect are similar to hers.

6 See Thornton (1982, 1988), Gilbert (1994) and Feinman (1993) for more history.

7 Data prepared by the Federal Reserve Bank of New York. Before August 10, 1989, the expected federal funds rate was sometimes given as a range; in these cases we have used the average of the range. Of the 45 target changes prior to 1994, seven were 7 basis points or less in absolute value. Preliminary tests indicate that the market did not respond to them, so they are not considered here.

8 That change occurred on April 18, 1994. See Pakko (1995). 
Table 1

\begin{tabular}{|c|c|c|c|}
\hline $\begin{array}{l}\text { Analytica } \\
\text { Federal F }\end{array}$ & $\begin{array}{l}\text { Breakdowr } \\
\text { nds Target }\end{array}$ & of Change & the \\
\hline & $\begin{array}{l}\text { Before Adoption } \\
\text { of Immediate } \\
\text { Disclosure Policy }\end{array}$ & $\begin{array}{l}\text { After Adoption } \\
\text { of Immediate } \\
\text { Disclosure Policy }\end{array}$ & Total \\
\hline $\begin{array}{l}\text { Total Changes } \\
\text { in Federal } \\
\text { Funds Target }\end{array}$ & 38 & 10 & 48 \\
\hline $\begin{array}{l}\text { Accompanied } \\
\text { by a Discount } \\
\text { Rate Change }\end{array}$ & 9 & 5 & 14 \\
\hline $\begin{array}{l}\text { Not Accompanied } \\
\text { by a Discount } \\
\text { Rate Change }\end{array}$ & 29 & 5 & 34 \\
\hline $\begin{array}{l}\text { Decided at } \\
\text { a Regular } \\
\text { FOMC Meeting }\end{array}$ & 9 & 9 & 18 \\
\hline $\begin{array}{l}\text { Decided Outside } \\
\text { a Regular } \\
\text { FOMC Meeting }\end{array}$ & 29 & 1 & 30 \\
\hline $\begin{array}{l}\text { Notes: Data for the } \\
\text { January 4, } 198 \\
\text { the poligy is fror } \\
\text { Source. Federal }\end{array}$ & $\begin{array}{l}\text { eriod before adoption } \\
\text { through December } 31 \\
\text { lanuary 1, 1994, thro }\end{array}$ & $\begin{array}{l}\text { of the immediate discl } \\
\text { 1993; the period cove } \\
\text { ugh January 31, } 1996\end{array}$ & $\begin{array}{l}\text { olicy cover } \\
\text { er adoption o }\end{array}$ \\
\hline
\end{tabular}

${ }^{9}$ For example, see Belongia and Kliesen (1994). It should be noted, however, that in only one of the eleven leaks that Belongia and Kliesen identify was the funds rate target changed. On the other ten occasions, the FOMC voted to leave policy unchanged.

${ }^{10}$ This paper deals only with the reaction of short-term interest rates. Roley and Sellon (1995) have investigated the immediate response of the 30-year Treasury bond rate to changes in the federal funds target rate and have found little evidence of an announcement effect. I also found little evidence of an announcement effect with the 30-year rate. rate target. Prior to 1994, sophisticated financial market participants attempted to decipher the Fed's intentions by monitoring, among other things, the behavior of the federal funds rate and the Fed's daily open market operations. Therefore, it would not be surprising to find an announcement effect associated with changes in the Fed's federal funds rate target prior to 1994. In addition, there were leaks to the press. ${ }^{9}$ Uncertainty about the Fed's intentions, however, might have produced a smaller announcement effect than that produced under certainty (see the appendix for details). In addition, because the deciphering process took time, the reaction to changes in the Fed's target rate might have been delayed.

To test for differences in the market's reaction to changes in the Fed's target for the funds rate before and after 1994, variations of the following equation were estimated:10
(1) $\Delta \mathrm{TB}_{\mathrm{t}}=\alpha+\beta_{0} \Delta \mathrm{fftar}_{\mathrm{t}}+\beta_{1} \Delta \mathrm{fftar}_{\mathrm{t}-1}+$ $\beta_{2} \Delta \mathrm{fftar}_{\mathrm{t}-2}+\ldots+\beta_{\mathrm{t}-\mathrm{j}} \Delta \mathrm{fftar}_{\mathrm{t}-\mathrm{j}}+\varepsilon_{\mathrm{t}}$,

where $\Delta \mathrm{TB}_{\mathrm{t}}$ denotes the one-day change in the 3-month T-bill rate, $\Delta$ fftar $_{t}$ denotes the change in the Fed's target for the federal funds rate on day $t$, and $\varepsilon_{t}$ denotes a random error. It is convenient to rewrite Equation 1 as:

$$
\begin{aligned}
& \text { (2) } \Delta \mathrm{TB}_{\mathrm{t}}=\alpha+\beta_{0} \Delta^{2} \mathrm{fftar}_{\mathrm{t}}+\gamma_{1} \Delta^{2} \mathrm{fftar}_{\mathrm{t}-1}+ \\
& \ldots+\gamma_{j-1} \Delta^{2} \text { fftar }_{\mathrm{t}-\mathrm{j}+1}+\theta \Delta \mathrm{fftar}_{\mathrm{t}-\mathrm{j}}+\varepsilon_{\mathrm{t}} \text {. }
\end{aligned}
$$

The two coefficients of interest are the immediate response, $\beta_{0}$, and the cumulative or total response, $\theta=\beta_{0}+\beta_{1}+\beta_{2}+$ $\ldots+\beta_{\mathrm{j}}$. If there is no delay in the market's response to changes in the federal funds rate target, the null hypothesis that $\beta_{0}=\theta$ should not be rejected.

Equation 2 is estimated with changes in the federal funds target partitioned into those before and after 1994. Changes in the Federal Reserve's discount rate, likewise partitioned, are added as a separate regressor. Approximately one-third of the changes in the funds target were accompanied by changes in the discount rate.

These estimates, presented in Table 2 with $\mathrm{j}=3$, show that an announcement effect was associated with changes in the Fed's funds rate target for periods after 1994, as well as before 1994. Consistent with the hypothesis that it took time for the market to decipher the Fed's policy intentions before the 1994 procedural change, the estimate of $\theta$ for the period before 1994 is somewhat larger than that of $\beta_{0}$. Moreover, the null hypothesis that $\beta_{0}=\theta$ is rejected at the 5 percent significance level, indicating a statistically significant delay in the market's response to changes in the funds rate target before 1994.

In contrast, for the period after 1994 the response is immediate. The null hypothesis $\beta_{0}=\theta$ cannot be rejected at any reasonable significance level. Moreover, the immediate response for the period after 1994 is nearly identical to the total response before 1994. The null hypothesis that these coefficients are equal is not rejected. The chi-square statistic is $\chi(1)=$ 0.0023 . 
$\mathrm{N}$ ot only was there an announcement effect before and after the FOMC adopted a policy of immediate disclosure, but the announcement effect was the same magnitude in both cases. The null hypothesis that the long-run effect of a change in the funds rate target is equal before and after 1994 is not rejected at the 5 percent significance level. The chi-square statistic is $\chi(1)=0.1682$. This last result suggests that the market was able to identify the new funds rate target within a few days of the change even before the policy of immediate disclosure was adopted. ${ }^{11}$

\section{The Market's Reaction with Discount Rate Changes}

Changes in the discount rate during the entire sample period were accompanied by changes in the Fed's target for the federal funds rate; the positive and statistically significant coefficient for changes in the discount rate before 1994 suggests that changes in the federal funds rate target had a larger effect when they were accompanied by discount rate changes than when they were not. M oreover, since discount rate changes are announced immediately and the Fed had frequently acknowledged that it intended to permit at least part of a discount rate change to "show through" to the federal funds rate, discount rate changes before the adoption of the immediate disclosure policy may have served as proxies for immediate disclosure.

The situation changed after 1994, however. The estimates in Table 2 indicate that, conditional on announcements of changes in its funds rate target, announcements of discount rate changes produced a perverse response: The T-bill rate changed less, on average, when there was also a change in the discount rate than it did when there was no accompanying discount rate change. The coefficient for changes in the discount rate is negative and statistically significant, despite the fact that the market reacted positively and significantly to changes in the discount rate alone (irrespective of changes in the funds rate target) before 1994. This result

\section{Table 2}

\begin{tabular}{|c|c|c|}
\hline Coefficient & $\begin{array}{c}\text { Before Disclosure Policy } \\
\text { January 4, 1988- } \\
\text { December 31, } 1993\end{array}$ & $\begin{array}{c}\text { After Disclosure Policy } \\
\text { January 1,1994- } \\
\text { January } 31,1996\end{array}$ \\
\hline$\alpha$ & $\begin{array}{l}0.0004 \\
(0.34)\end{array}$ & -- \\
\hline$\beta_{0}$ & $\begin{array}{l}0.2553^{*} \\
(4.75)\end{array}$ & $\begin{array}{l}0.3677^{*} \\
(4.26)\end{array}$ \\
\hline$\theta$ & $\begin{array}{l}0.3627^{*} \\
(5.04)\end{array}$ & $\begin{array}{l}0.3122^{*} \\
(3.28)\end{array}$ \\
\hline$\Delta \mathrm{DR}$ & $\begin{array}{l}0.1373^{*} \\
(3.17)\end{array}$ & $\begin{array}{c}-0.1937^{*} \\
(2.05)\end{array}$ \\
\hline$\sigma_{\epsilon}$ & 0.0476 & -- \\
\hline Adj $R^{2}$ & 0.0886 & -- \\
\hline D.W. Statistic & 1.8442 & -- \\
\hline Test $\beta_{0}=\theta$ & $4.9388^{*}$ & 0.7320 \\
\hline \multicolumn{3}{|c|}{$\begin{array}{l}\text { Notes: Test } \beta_{0}=\theta \text { was based on a Wald test. The test statistic is distributed Chi Square } \\
\text { with one degree of freedom, with a critical value at the } 5 \text { percent level of } 3.84 \text {. } \\
\text { The estimated t-statistics, presented below the coefficient estimates in parentheses, are } \\
\text { based on White's (1980) heteroskedastiaty-adjusted standard errors. } \\
\text { * Indicates statistical significance at the } 5 \text { percent level. }\end{array}$} \\
\hline
\end{tabular}

was unanticipated and is difficult to interpret. See the shaded insert on page 7 for one possible explanation.

In any event, if changes in the discount rate prior to 1994 served as proxies for immediate disclosure of the Fed's policy decisions, it is reasonable to conjecture that there would be no delay in the response to changes in the funds rate target, since they had al ready been "announced" by discount rate changes. On the other hand, when the disclosure was not immediate, the market response would have lasted as long as it took the market to decipher whether there was, in fact, a change in the target.

To test this conjecture, Equation 2 was estimated with changes in the funds rate target during the period before adoption of the immediate disclosure policy partitioned into those with (W) and without (WO) discount rate changes. The estimates, presented in Table 3, support
${ }^{11}$ This conclusion is based on the assumption that the market's reaction to changes in the funds rate target was the same in both periods. See the appendix for additional details. 
Table 3

\section{Estimates of Market Reactions to Changes in the Federal Funds Rate Target With and Without Discount Rate Changes}

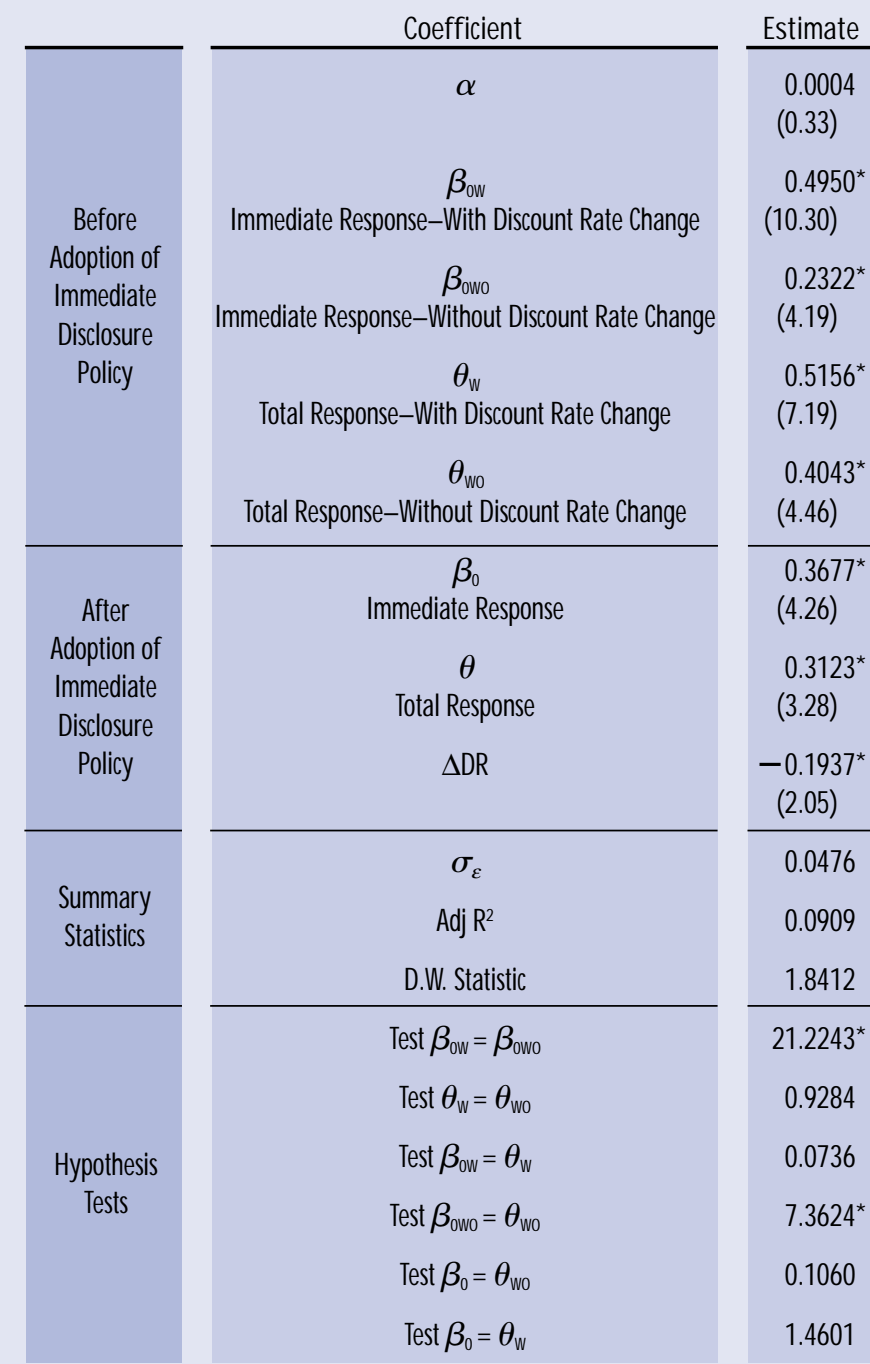

Notes: Period before adoption of immediate disclosure policy covers January 4, 1988, through December 31, 1993; period after adoption covers anuary 1, 1994, through January 31, 1996. Hypothesis tests are based on a Wald test. The test statistic is distributed Chi Square with one degree of freedom, with a critical value at the 5 percent level of 3.84. The estimated $t$-statistics, presented below the coefficient estimates in parentheses, are based on White's (1980) heteroskedasticity-adjusted standard errors. * Indicates statistical significance at the 5 percent level.

the conjecture that, prior to 1994 , discount rate changes served as proxies for immediate disclosure of policy decisions. The market appears to have reacted immediately to federal funds rate target changes accompanied by discount rate changes, but it had a delayed reaction to those that were not. The market's immediate response to changes in the federal funds target that were accompanied by discount rate changes was more than double the response to changes in the funds rate target that were not accompanied by discount rate changes. The fact that the total responses with and without discount rate changes are similar suggests that the only difference is immediate disclosure. Indeed, the null hypothesis that these coefficients are equal cannot be rejected at any reasonable significance level.

Again, the evidence suggests that the magnitude of the announcement effect has been the same since the Fed adopted the policy of immediate disclosure as it was before. Despite the fact that the total response before 1994, with and without discount rate changes, is larger than for the period after 1994, the null hypothesis that each total response is equal to the total response after 1994 cannot be rejected at the 5 percent significance level.

These results suggest that the Fed's concern that immediate disclosure of its policy decisions would produce an announcement effect was unwarranted. An announcement effect is evident with or without immediate discl osure. M oreover, the evidence suggests that the magnitude of the announcement effect has been unchanged by the policy of immediate disclosure. If anything, the announcement effect has become smaller; however, the difference is not statistically significant.

In the period studied, there is a delay in the market's reaction when disclosure is not immediate, but no delay when it is immediate. This difference suggests that, when the market is well informed, it incorporates new information quickly. When it is not, investors are able to sort out the policy signals from market noise, but only after an expenditure of time and resources.

Finally, it should be noted that there is another difference in the Fed's behavior before and after 1994 that should be examined for possible effects on market response. Since the adoption of the policy 
of immediate disclosure, all but one of the policy decisions have been made at regularly scheduled meetings of the FOMC. Before 1994, only about onefourth of the changes in the funds rate target occurred at regularly scheduled meetings of the FOMC. FOMC meetings generally occur on Tuesday, except for the two-day meetings, which occur on Tuesday and Wednesday. Consequently, it is possible that responses to announcements al so exhibit a day-of-the-week effect. To investigate this possibility, Equation 2 was estimated with changes in the funds rate target before 1994 partitioned into those that occurred on meeting dates and those that did not. The results, presented in the appendix, suggest that no day-of-the-week effect was associated with market responses to changes in the funds rate target.

\section{Does Immediate Disclosure Increase or Decrease Uncertainty?}

A second obstacle to adopting a policy of immediate disclosure of policy decisions was the Fed's concern that it would increase market uncertainty. The idea that more information increases uncertainty runs counter to economic theory (Arrow, 1971). Hirshleifer (1971) and Starr (1973) show how publicly disclosed information enhances social welfare, and O'Brien (1981, 1984) presented evidence that market uncertainty would be reduced if the FOMC followed a procedure of immediate disclosure.

A natural measure of uncertainty is the error that individuals make in forecasting the future. If there were no uncertainty about the Fed's target for the funds rate, individuals' forecasts of the interest rate would fall within the range of random error. ${ }^{12}$ One measure of uncertainty is the mean square error (M SE) - the average squared distance between the actual and forecasted value of the variable being examined - in this case, the federal funds rate. The MSE at the jth time horizon is given by:

$$
M E^{j}(i)=E\left(i_{t+j}-i_{t+j}^{f}\right)^{2},
$$

where $i_{t+j}^{f}$ denotes the market's forecast of the interest rate at date $t+j$. If the disclosure of information increases market uncertainty, the MSE should also increase. Alternatively, if it reduces uncertainty, the M SE should fall. ${ }^{13}$ The MSEj(i) declines when more information becomes available.

To test whether the Fed's new disclosure policy has increased or decreased market uncertainty, we need a measure of market expectations for the future funds rate. A natural place to turn is the federal funds futures market. ${ }^{14}$ (See the shaded insert on page 8 for a brief description of this market). Generally speaking, futures contracts are used to speculate on or hedge against price movements. The same is true of the federal funds futures contracts, except that individuals who are unable to buy or sell federal funds can, nevertheless, participate. ${ }^{15}$

The important aspect of this market is that the federal funds futures rate is an indicator of the rate anticipated by those participating in the market. Hence, we can test whether the Fed's new disclosure policy increased or decreased the market's uncertainty by examining whether the MSE of the federal funds futures market increased or decreased. Because the M SE gives a great deal of importance to unusually large forecast errors, the mean absolute forecast error, $M A E$, is also presented.

The MSE, the MAE, and the average forecast error for current, one-month and two-month federal funds futures contracts, before and after 1994 are presented in Table 4. The average forecast errors are small at the respective horizons for the two periods. The null hypothesis that the average forecast error, AFE, is zero is not rejected for any horizon for the period after 1994, but it is rejected at the 1- and 2-month horizons for the period before 1994.

Both measures of market uncertaintyMSE and MAE - reveal a marked decline in market uncertainty after the Fed's new disclosure policy. This finding is consistent with economic theory: that immediate disclosure of policy actions appears to reduce market uncertainty. This conclusion, however, should be weighed carefully. It may be that the marked reduction in uncer-
${ }^{12}$ See the appendix for details about this assertion and others in this section.

${ }^{13}$ The implicit assumption, of course, is that the information being disclosed is useful for determining the variable being forecast ( see the appendix for details).

${ }^{14}$ See Goodfriend and Whelpley (1993) for a discussion of who can participate in the overnight federal funds market.

${ }^{15}$ Krueger and Kuttner (1995) and Carlson, Mclntire and Thomson (1995) show that the federal funds futures market is generally efficient in that the forecasts are unbiased and the forecast errors are uncorrelated with past information. Using these data, I was able to replicate the average forecast errors and MSE of Carlson, McIntire and Thomson (1995) over their sample periods. 
Table 4

\begin{tabular}{|c|c|c|c|c|c|c|}
\hline \multirow{3}{*}{$\begin{array}{c}\text { Errors i } \\
\text { Variable }\end{array}$} & \multirow{2}{*}{\multicolumn{3}{|c|}{ Before Disclosure Policy }} & \multirow{2}{*}{\multicolumn{3}{|c|}{ After Disclosure Policy }} \\
\hline & & & & & & \\
\hline & Current & 1-Month & 2-Month & Current & 1-Month & 2-M onth \\
\hline AFE & -0.0137 & -0.0650 & -0.1285 & -0.0123 & -0.0245 & -0.0233 \\
\hline MSE & 0.0046 & 0.0352 & 0.1014 & 0.0039 & 0.0143 & 0.0315 \\
\hline MAE & 0.0491 & 0.1379 & 0.2398 & 0.0394 & 0.0898 & 0.1507 \\
\hline
\end{tabular}

Notes: Period before adoption of immediate disclosure policy covers October 1988 through December 1993; period after adoption of immediate disclosure covers ) anuary 1994 through January 1996.

AFE is equal to $\sum \varepsilon_{i} / n$, where $\varepsilon_{i}$ is the $i^{\text {th }}$ month's forecast error.

MSE is equal to $\sum \varepsilon_{i}^{2} / n$.

MAE is equal to $\sum\left|\varepsilon_{i}\right| / n$.

\section{Table 5}

Forecasts of Federal Funds Futures Market and Statistical Models

\begin{tabular}{|c|c|c|c|c|c|c|c|}
\hline & & \multicolumn{3}{|c|}{ 1-M onth Horizon } & \multicolumn{3}{|c|}{ 2-Month Horizon } \\
\hline & & Futures & Naive & AR & Futures & Naive & AR \\
\hline \multirow{2}{*}{$\begin{array}{l}\text { Before } \\
\text { Disclosure } \\
\text { Policy }\end{array}$} & MSE & 0.0352 & 0.0436 & $0.0303^{1}$ & 0.1014 & 0.1327 & $0.0422^{3}$ \\
\hline & MAE & 0.1379 & 0.1648 & 0.1386 & 0.2398 & 0.2926 & 0.1628 \\
\hline \multirow{2}{*}{$\begin{array}{l}\text { After } \\
\text { Disclosure } \\
\text { Policy }\end{array}$} & MSE & 0.0143 & 0.0319 & $0.0262^{2}$ & 0.0315 & 0.0835 & $0.0382^{4}$ \\
\hline & MAE & 0.0898 & 0.1512 & 0.1278 & 0.1507 & 0.2808 & 0.1660 \\
\hline
\end{tabular}

Note: Period before adoption of immediate disclosure policy covers October 1988 through December 1993; period after adoption of immediate disclosure covers ) anuary 1994 through J anuary 1996.

${ }^{1}$ The estimated AR(2) process is: $u_{t}=0.3943^{*} u_{t-1}+0.2142 u_{t-2}+\varepsilon_{t}$, where $*$ indicates statistical significance at the 5 percent level.

${ }^{2}$ The estimated AR(2) process is: $u_{t}=0.2362 u_{t-1}+0.2342 u_{t-2}+\varepsilon_{t}$

${ }^{3}$ The estimated AR(2) process is: $u_{t}=1.0186 * u_{t-1}-0.2592 * u_{t-2}+\varepsilon_{t}$

${ }^{4}$ The estimated AR(2) process is: $u_{t}=0.7275^{*} u_{t-1}+0.0122 u_{t-2}+\varepsilon_{t}$

tainty is actually the result of a decline in the general volatility of the funds rate over the later period, rather than a genuine reduction in uncertainty. Indeed, the standard deviation of the federal funds rate, which was 2.50 before 1994 , declined to 0.99 after 1994. While the standard deviation is affected by the level of interest rates, there was also a marked decline in another measure, the coefficient of variation, which is not. The coefficient of variation, which was 0.41 before 1994, declined to 0.20 after 1994.

Also, the reduction in variability may be related to factors other than the FOMC's new disclosure policy. The federal funds futures market is a developing market. Over the period of this analysis, the volume of trading in the market has increased significantly (Carlson, M clntire, and Thomson, 1995). In particular, there has been a very substantial rise in the volume of trading since the beginning of 1994. Hence, some or all of the reduction in variability may reflect the increased trading volume, rather than the change in disclosure policy.

One way to assess whether the declines in MSE and MAE, shown in Table 4 , are related to a reduction in market uncertainty, rather than to a decline in the variability of the federal funds rate or the 


\section{THE UNUSUAL RESPONSE TO DISCOUNT RATE CHANGES UNDER IMMEDIATE DISCLOSURE}

One possible explanation for the unusual response of the T-bill rate to changes in the Federal Reserve discount rate under the Fed's policy of immediate disclosure is that, prior to the Fed's new disclosure policy, the market viewed changes in the discount rate as a signal that the Fed had changed its target for the funds rate. Hence, given the Fed's immediate disclosure policy, the signaling aspect of discount rate changes is redundant. Consequently, the market may have struggled with how to interpret discount rate changes in the new environment.

There is a possibility that the market may be confused by the combination of two announcements- that the Fed has changed its monetary policy stance and that the discount rate has also changed. A well-documented observation (Thornton, 1982, 1986, and 1996b; Cook and Hahn, 1988; and Smirlock and Yawitz, 1985) is that markets do not respond to discount rate changes that the Fed indicates are solely to realign the discount rate with market rates (that is, technical discount rate changes). As I have shown (Thornton, 1996a), this lack of market response may be attributed to the fact that such announcements provide no useful information.

Since, under the immediate disclosure policy, the Fed acknowledges policy changes as soon as they are approved, the market may regard any subsequent or accompanying discount rate changes as merely technical adjustments, made solely to realign the discount rate with the new level of the federal funds rate. In fact, the Fed announced that these changes were made for reasons other than simply to align the discount rate. Indeed, on only one of these occasions did the Fed even mention technical realignment as one of the reasons for the change. Given the limited number of changes in the funds target and the discount rate under the new disclosure policy, however, it is difficult to identify a reason for the unusual response of the T-bill rate to changes in the discount rate. federal funds futures market, is to compare the forecasting ability of the futures market with that of statistical models before and after 1994. If the apparent improvement in the forecasting ability of the futures market is due solely to the reduction in variability of the funds rate, there should be a similar improvement in the forecasting ability of statistical models. ${ }^{16}$

Two statistical models, similar to those used by Carlson, Mclntire, and Thomson (1995), are used. The first assumes that the best predictor of this month's federal funds rate is last month's federal funds rate. That is,

$$
\begin{aligned}
& r_{t}=r_{t-1}+\varepsilon_{t} \text {, for the 1-month horizon } \\
& \text { and } \\
& r_{t}=r_{t-2}+\varepsilon_{t} \text {, for the 2-month horizon. }
\end{aligned}
$$

This is called the naive forecast. The sec- ond model assumes that the change in the federal funds rate is modeled as a sec-ondorder autoregressive process. That is,

$$
(1-\mathrm{L}) \mathrm{r}_{\mathrm{t}}=\alpha(1-\mathrm{L}) \mathrm{r}_{\mathrm{t}-1}+\beta(1-\mathrm{L}) \mathrm{r}_{\mathrm{t}-2}+\varepsilon_{\mathrm{t}}
$$

for the 1-month time horizon and

$$
\left(1-\mathrm{L}^{2}\right) \mathrm{r}_{\mathrm{t}}=\alpha\left(1-\mathrm{L}^{2}\right) \mathrm{r}_{\mathrm{t}-1}+\beta\left(1-\mathrm{L}^{2}\right) \mathrm{r}_{\mathrm{t}-2}+\varepsilon_{\mathrm{t}}
$$

for the 2-month time horizon, where $L$ denotes the lag operator, that is, $L Y_{t}=L Y_{t-1}$. This is called the autoregressive (AR) forecast. $^{17}$

The MSE and MAE for the three forecasts are presented in Table 5. The MSE and MAE for the statistical models show a marked decline after 1994, suggesting that part of the improvement in the futures market forecast is the result of a reduction in the volatility of the funds rate. The improvement in the futures market fore-
${ }^{16}$ The converse - that if the improvement is solely due to reduced uncertainty, there will be no improvement in the statistical models- is only strictly true for the naive model. It is not necessarily true for the $A R$ model.

${ }^{17}$ These equations were estimated in the form $\Delta i_{t}=\gamma+u_{t}$ where $u_{t}=\alpha u_{t-1}+B u_{t-2}+\varepsilon_{t}$, by employing a transformation that maintains all of the observations. For a discussion of why it is important to keep all of the observations, especially in small samples, see Thornton (1987). 


\section{FEDERAL FUNDS FUTURES AND THE FEDERAL FUNDS RATE}

A federal funds futures contract is designed to hedge against or speculate on future movements in the federal funds rate by calling for the payment of interest on a $\$ 5$ million contract that is equal to the monthly average of the daily federal funds rate during the contract month. The settlement price of the contract is equal to 100 minus the average of the daily overnight federal funds rate during the month of the contract. Consequently, the future's market forecast of the federal funds rate is implied by the price of the contract. For example, assume that on December 10 the market believes that the federal funds rate will average 5.47 percent ( 100 94.53) in January. Individuals who believe that the funds rate will rise will be willing to pay a lower price for the contract. Individuals who believe that the rate will fall will be willing to pay a higher price.

When the contract is initiated, no funds change hands; however, buyers and sellers are required to establish margin accounts with their brokers. Moreover, there is no promise to deliver federal funds on the settlement date, as is typically the case in commodities markets. Rather, dollars are transferred between the margin accounts of buyers and sellers each day as the price of the contract changes. For example, assume that the one-month contract that traded for 94.53 on December 10 trades for 94.52 on December 11, indicating that the market believes that the funds rate will average one basis point (one "tick") higher in January than the guess of the day before. The market would "settle" that day by transferring $\$ 41.67$ ( 0.01 percent $\times 30 / 360 \times \$ 5$ million) from the buyer's margin account to the seller's margin account for each contract held by the buyer.

cast is somewhat better than that of the statistical models, however. For example, at the 1-month horizon, the M SE for the futures market forecast was reduced to 41 percent of its pre-1994 level, compared to 73 percent and 86 percent for the naive and AR models, respectively. At the 2month horizon, the MSE for the futures market forecast was reduced to 31 percent of its former level, compared with 63 percent and 91 percent, respectively, for the naive and AR models. Qualitatively similar results are obtained with $M A E$.

The larger relative reduction in the forecast error suggests the possibility that some of the improvement in futures market forecasting in the latter period stems from reduced uncertainty associated with the Fed's policy of immediate disclosure. In particular, the AR model and the federal funds futures market did about equally well by MSE and MAE before $1994 .{ }^{18}$ After 1994, however, the futures market forecast out-performed the AR forecast by these criteria at the 1-month horizon. In any event, the results in Tables 4 and 5 suggest that the Fed's policy of immediate disclo-sure did not increase the market's uncertainty and may have reduced it.

\section{CONCLUSIONS}

Over the years, the Federal Reserve has been criticized for being too secretive about its monetary policy decisions. In the past, the Fed argued that the immediate disclosure of its policy decisions would create an announcement effect and increase market uncertainty. Critics countered that providing the market with more and more timely information would reduce market uncertainty. Despite these criticisms and Congressional pressure, the Fed maintained a policy of delayed disclosure until the February 1994 meeting of the FOMC, when it abruptly broke its long-standing tradition and immediately disclosed its decision to raise its target for the federal funds rate.

This article examines whether the change in the Fed's disclosure policy at the 
first meeting of the FOMC in 1994 created an announcement effect and increased market uncertainty. Contrary to past claims, the evidence indicates that there was an announcement effect prior to the FOMC's recent change in its disclosure policy. Furthermore, the magnitude of the announcement effect was not changed by immediate disclosure. The main difference is that the announcement effect occurs at once under immediate disclosure. In contrast, the announcement effect was strung out over several days when the market was left to decipher policy changes on its own.

The evidence also suggests that financial-market volatility and uncertainty have not been increased by a policy of immediate disclosure, and may actually have been reduced. The federal funds rate is less volatile since the FOMC has adopted a policy of immediate disclosure. This decrease in volatility could be a result of factors other than, or in addition to, the change in disclosure policy. Even when the reduction in volatility is accounted for, however, there is evidence of a reduction in uncertainty about the federal funds rate after 1994. There has been a marked improvement in forecasts by the federal funds rate futures market relative to statistical models since the disclosure policy was implemented. Overall, the evidence suggests that the Fed's policy of immediate disclosure has been beneficial. In monetary policy, as in most other areas of economics, more information is preferable to less.

\section{REFERENCES}

Arrow, Kenneth J. "The Value of and Demand for Information," Essays in the Theory of Risk Bearing, Marham Publishing Company, 1971, pp. 267-78.

Belongia, Michael T. and Kevin L. Kliesen. "Effects on Interest Rates of Immediately Releasing FOMC Directives," Contemporary Economic Policy (October 1994), pp. 79-91.

Board of Governors of the Federal Reserve, Federal Reserve Bulletin (March 1995), p. 265.

Carlson, John B., Jean M. McIntire, and James B. Thomson. "Federal Funds Futures as an Indicator of Future Monetary Policy: A Primer,"
Economic Review, Federal Reserve Bank of Cleveland (First Quarter 1995), pp. 20-30.

Cook, Timothy and Thomas Hahn. "The Information Content of Discount Rate Announcements and Their Effect on Market Interest Rates," Journal of Money, Credit and Banking (May 1988), pp. 167-80.

Federal Open Market Committee of the Federal Reserve System. Petition for a Writ of Certiorari to the United States Court of Appeals for the District of Columbia Circuit, October Term, 1977.

Feinman, Joshua N. "Estimating the Open Market Desk's Daily Reaction Function," Journal of Money, Credit and Banking (May 1993), pp. 231- 47.

Gilbert, R. Alton. "A Case Study in Monetary Control: 1980-82," this Review (September/ October 1994), pp. 35- 55.

Gonzalez, Henry B. "The Federal Reserve's 17- Year Secret," Committee on Banking, Finance and Urban Affairs, United States House of Representatives, January 27, 1994.

Goodfriend, Marvin. "Monetary Mystique: Secrecy and Central Banking," Journal of Monetary Economics (January 1986), pp. 63- 92. and William Whelpley. "Federal Funds," in Timothy Q. Cook and Robert K. LaRoche, eds., Instruments of the Money Market, Federal Reserve Bank of Richmond, 1993, pp. 7-21.

Hirshleifer, Jack. "The Private and Social Value of Information and the Reward to Inventive Activity," The American Economic Review (September 1971), pp. 561- 74.

Krueger, Joel T., and Kenneth N. Kuttner. "The Fed Funds Futures Rate as a Predictor of Federal Reserve Policy," Federal Reserve Bank of Cleveland working paper, WP-95-4, March 1995.

O'Brien, James M. "The Information Value of the FOMC Policy Directive under the New Operating Procedures," Journal of Money, Credit and Banking (May 1984), pp. 151- 64.

"Estimating the Information Value of Immediate Disclosure of the FOMC Policy Directive," The J oumal of Finance (December 1981), pp. 1047-61

Pakko, Michael R. "The FOMC in 1993 and 1994: Monetary Policy in Transition," this Review (March/ April 1995), pp. 3- 25.

Roley, V. Vance and Gordon H. Sellon, Jr. "Monetary Policy Actions and Long-Term Interest Rates," Economic Review, Federal Reserve Bank of Kansas City (Fourth Quarter, 1995), pp. 73- 89.

Smirlock, Michael J., and J ess B. Yawitz. "Asset Returns, Discount Rate Changes, and Market Efficiency," Journal of Finance (September 1985), pp. 1141- 58. 


\section{REVIEW \\ November/ December 1996}

Starr, Ross M. "Optimal Production and Allocation Under Uncertainty," Quarterly Joumal of Economics (February 1973), pp. 81- 95.

Thornton, Daniel L. "Information Content of Discount Rate Announcements: What's Behind the Announcement Effect?" unpublished manuscript, Federal Reserve Bank of St. Louis, 1996a.

. . . _. _ . " "The Discount Rate Policies of Five Federal Reserve Chairmen," unpublished manuscript, Federal Reserve Bank of St. Louis, 1996b.

_. _. _ . . "Why Do T-Bill Rates React to Discount Rate Changes?" Joumal of Money, Credit and Banking (November 1994), pp. 839- 50

_. . "The Borrowed-Reserves Operating Procedure: Theory and Evidence," this Review (Januaryl February 1988), pp. 30- 54.

"A Note on the Efficiency of the Cochrane-Orcutt Estimator of the AR(1) Regression Model," Journal of Econometrics (November 1987), pp. 369- 76

. "The Discount Rate and Market Rates: Theory and Evidence," this Review (August/ September 1986), pp. 5- 21.

. . "The FOMC in 1981: Monetary Control in a Changing Financial Environment," this Review (April 1982), pp. 3- 22.

Whalen, Christopher. "Fed's Secretive Decisions Need 'Sunshine'," The Christian Science Monitor (October 28, 1993), p. 19. 
The purpose of this appendix is to elaborate on various claims made in the text and to show how uncertainty about the Fed's policy can result in a smaller market reaction.

\section{Market Uncertainty About Changes} in the Federal Funds Target Rate

To see how uncertainty can affect the market's reaction to changes in the Federal Reserve target for the federal funds rate, let $\chi$ denote the market's reaction to a change in the target under perfect certainty, and let $P$ denote the market's subjective estimate of the probability that the Fed will change its target. The actual response, $X$, to a change in the Fed's target is represented by the following equation:

$$
X_{t}=P \chi_{t}+(1-P) W_{t},
$$

where $\mathrm{W}$ denotes the market's reaction to no change in the policy target, i.e., $W=0$. $N$ ote that unless the public is certain that the Fed has changed its federal funds target, i.e., $P=1$, the actual market reaction will always be smaller than its reaction under certainty. Hence, when the public is uncertain about changes in the federal funds rate target, $\mathrm{X}=\mathrm{P} \chi<\chi$, the response under certainty.

\section{Claims About Forecast Errors and the MSE in This Article}

To establish claims made in this article, assume that the variable being forecasted, i, is generated by the following data generating function:

$$
\mathrm{i}_{\mathrm{t}}=\mathrm{f}\left(\mathrm{Z}_{\mathrm{t}}\right)+\varepsilon_{\mathrm{t}},
$$

where $Z$ is a set of variables that determines $i$, including the monetary authority's policy directive, and $\varepsilon$ is a random variable that is independently and identically distributed with a mean of zero and a variance of $\sigma^{2}$, that is, $\varepsilon \sim$ iid $\left(0, \sigma^{2}\right)$. Even if the mean and variance of $\varepsilon$ were known, the precise outcome of $\varepsilon_{\mathrm{t}}$ for any time $t$ could not be predicted. Hence, in a world of perfect certainty, the market would know only $f(\cdot), Z$ and the mean and variance (and perhaps higher moments) of the distribution of $\varepsilon$. Under perfect certainty, the forecast value of $\mathrm{i}$ in period $\mathrm{t}+\mathrm{j}$ would be

$$
i_{t+j}^{f}=f\left(Z_{t+j}\right) .
$$

Hence,

$$
\begin{gathered}
(A .4) \quad M^{M S E^{j}(i)}=E\left(i_{t+j}-i_{t+j}^{f}\right)^{2}= \\
E\left[f\left(Z_{t+j}\right)+\varepsilon_{t+j}-f\left(Z_{t+j}\right)\right]^{2}=E\left(\varepsilon_{t+j}^{2}\right)=\sigma^{2} .
\end{gathered}
$$

$N$ ote that this result requires forecasters to know future values of the variables that determine $i$, that is, $Z_{t+j}$ and the precise function that generates the data, that is, $f(\cdot)$. In the case where this information is unknown or uncertain, Equation A.4 can be rewritten as

$$
\begin{aligned}
& \text { (A.5) } \quad M \mathrm{MSE}^{\mathrm{j}}(\mathrm{i})=\mathrm{E}\left(\mathrm{i}_{\mathrm{t+j}}-\mathrm{i}_{\mathrm{t+j}}^{\mathrm{f}}\right)^{2}= \\
& E\left[f\left(Z_{t+j}\right)+\varepsilon_{t+j}-f f\left(Z_{t+j}^{f}\right)\right]^{2}= \\
& E\left[f\left(Z_{t+j}\right)-f^{f}\left(Z_{t+j}^{f}\right)\right]^{2}+\sigma^{2} \text {. }
\end{aligned}
$$

In this case, the forecast error depends on both the underlying randomness in the data-generating process and the market's inability to know precisely the details of the underlying data-generating function. Anything that reduces uncertainty with respect to the underlying data-generating function will reduce the MSE of the forecast.

\section{Tests of the Market's Response on Meeting Dates and 0 ther Dates}

Because nearly all of the changes in the funds rate target since 1994 have been decided at regularly scheduled FOMC meetings, whereas before 1994 only about one-fourth of the changes occurred at regularly scheduled FOMC meetings, and 


\section{Table A1}

\section{Estimates of Market Reactions to Changes in the Federal Funds Rate Target on Meeting Dates and Other Dates}

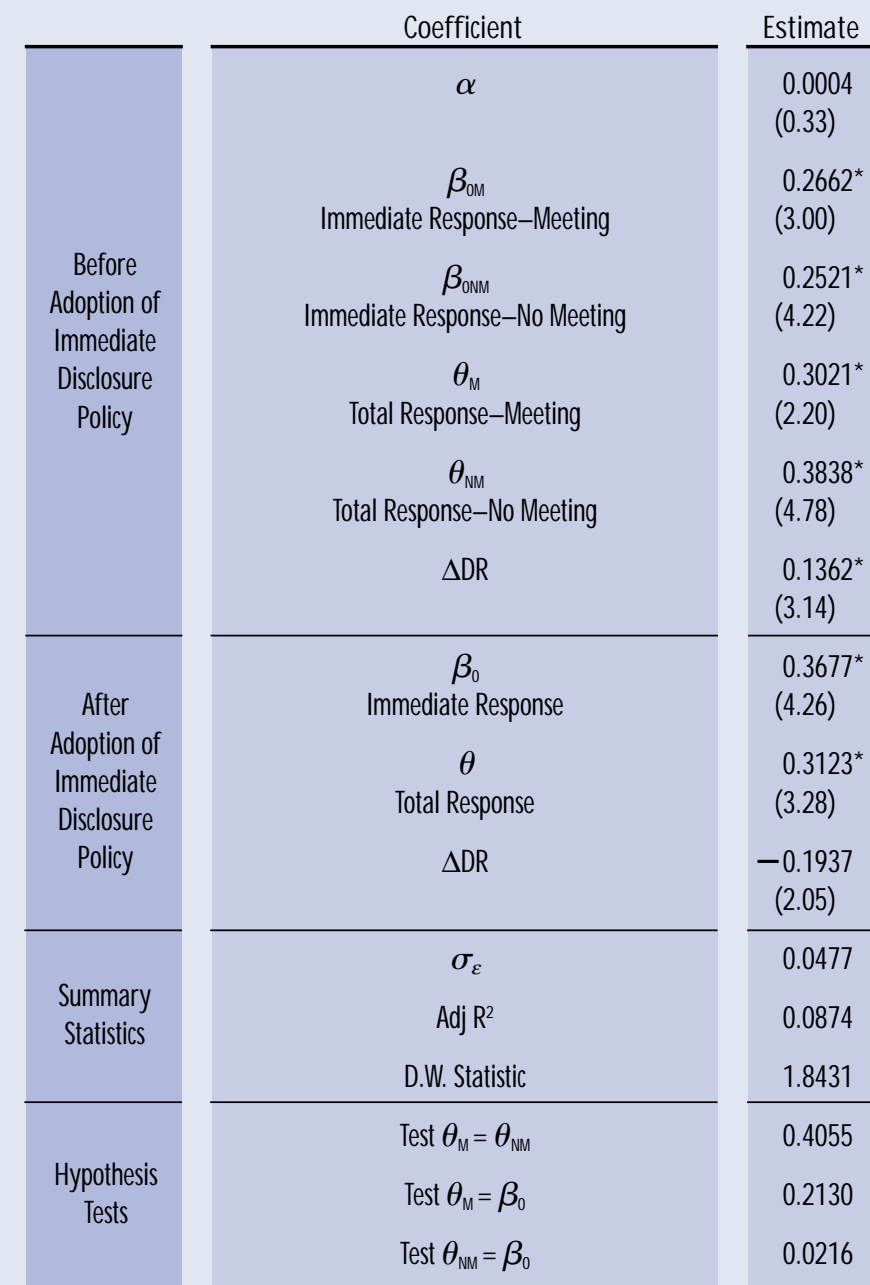

Notes: Period before adoption of immediate disclosure policy covers J anuary 4, 1988, through December 31, 1993; period after adoption covers / anuary 1, 1994, through January 31,1996 . Hypothesis tests are based on a Wald test. The test statistic is distributed Chi Square with one degree of freedom, with a critical value at the 5 percent level of 3.84. The estimated $\mathrm{t}$-statistics, presented below the coefficient estimates in parentheses, are based on White's (1980) heteroskedasticity-adjusted standard errors. * Indicates statistical significance at the 5 percent level.
${ }^{18}$ Since only one change in the federal funds rate target after 1994 was made at a time outside the regularly scheduled meetings, the estimates for this period are based on all changes in the funds rate, including the non-meeting change. because FOM C meetings have generally been held on the same days of the week, it is possible that the response of the T-bill rate reflects a day-of-the-week effect. To investigate this possibility, changes in the funds rate target before 1994 were partitioned into those that were decided at regularly scheduled FOMC meetings (M) and those that did not (NM). An equation analogous to Equation 2 was estimated with the data so partitioned. ${ }^{18}$ The results, reported in Table A1, reveal no day-of-theweek effect. The total responses to changes in the target rate, whether or not those changes were decided upon at regularly scheduled meetings, are similar to the immediate responses to changes decided upon in regular meetings. Each of three possible combinations of these hypotheses is not rejected. The fact that there is a statistically significant delay in the response of the market when there is no meeting but no significant delay when there is a meeting appears to reflect the fact that only three of the nine discount rate changes before 1994 occurred at regularly scheduled FOMC meetings. 